\title{
Penentuan Formulasi Empiris Yang Sesuai Untuk Mengestimasi Kurva Intensitas Durasi Frekuensi
}

\section{Determination of An Appropriate Empirical Formula for Estimating Intensity Duration Frequency Curve}

\author{
Donny Harisuseno $^{1^{*}}$, Sri Wahyuni ${ }^{1}$, Yosie Dwirani ${ }^{1}$ \\ ${ }^{1}$ Jurusan Teknik Pengairan, Fakultas Teknik, Universitas Brawijaya, Malang 65145, Indonesia
}

\author{
Article info: \\ Kata kunci: \\ hasper der wedumen, intensitas hujan, \\ kurva IDF, mononobe, talbot, van \\ breen,
}

\section{Keywords:}

hasper der weduwen, mononobe, rainfall intensity, talbot, van breen,

\section{Article history:}

Received: 01-09-2019

Accepted: 28-05-2020

*)koresponden email: donnyhari@ub.ac.id

\begin{abstract}
Abstrak
Intensitas hujan yang tinggi akan menyebabkan limpasan permukaan yang besar dan dapat berdampak negatif. Kurva IDF mempermudah perhitungan debit banjir rencana. Tujuan penelitian ini adalah menentukan metode empiris intensitas hujan dan IDF yang cocok untuk lokasi penelitian. Metode yang digunakan adalah Talbot, Mononobe, Hasper Der Weduwen, dan Van Breen. Hasil perhitungan menunjukkan bahwa Metode Talbot yang paling sesuai digunakan di lokasi penelitian. Metode Talbot memiliki nilai Deviasi Rata-rata 1.49; Kesalahan Relatif (Kr) rata-rata sebesar 8.64\% dan Koefisien Nash Sutcliffe (ENS) rata-rata sebesar 0.98. Kemudian dilakukan validasi metode terpilih menggunakan kala ulang 2 tahun dan 5 tahun dengan membandingkan intensitas hujan metode empiris dan intensitas hujan pengamatan dengan hasil nilai Deviasi Rata-rata sebesar 2.22; nilai Kesalahan Relatif (Kr) rata-rata sebesar 15.11\%, dan Koefisien Nash Sutcliffe (ENS) rata-rata sebesar 0.93 .
\end{abstract}

\begin{abstract}
High rainfall intensity will cause large surface runoff and can lead to negative effects. The IDF curve makes it easy to calculate the design flood. The purpose of this study is to determine the empirical method of rainfall intensity and IDF that are suitable for the study location. The methods used are Talbot, Mononobe, Hasper Der Weduwen, and Van Breen. The result of the calculation found that the most suitable method for this location is Talbot Method. The Talbot Method has an Average Deviation of 1.49, an Average Relative Error of 8.64\%, and the Average of Nash-Sutcliffe Efficiency Coefficient (NSE) by 0.98. Then the calculations for the validation of the selected method is using a 2-year return period and 5-year return period have the results of an Average Deviation value of 2.22, the Average Relative Error value of $15.11 \%$ and the Average of Nash-Sutcliffe Efficiency Coefficient (NSE) by 0.93 .
\end{abstract}

Kutipan: Harisuseno, D., Wahyuni, S., \& Dwirani, Y. (2020). Penentuan Formulasi Empiris Yang Sesuai Untuk Mengestimasi Kurva Intensitas Durasi Frekuensi. Jurnal Teknik Pengairan. https://doi.org/10.21776/ub.pengairan.2020.011.01.06

\section{Pendahuluan}

Permasalahan sumber daya air pada umumnya sangat berkaitan dengan kejadian debit banjir besar (banjir) dan debit aliran rendah (kekeringan). Kejadian hujan dengan intensitas hujan yang tinggi yang terjadi pada musim hujan memberikan dampak meningkatnya debit limpasan permukaan yang pada gilirannya akan menyebabkan terjadinya banjir di wilayah tertentu (Guntoro, Harisuseno, and Cahya 2017). Limpasan permukaan yang berlebihan pada musim hujan membutuhkan bangunan drainase guna mengurangi dampak genangan pada permukaan lahan (Rismasari, Harisuseno, and 
Hendrawan 2018). Bangunan drainase yang baik adalah bangunan yang direncanakan dengan baik, dimana dalam perencanaan ini membutuhkan intensitas curah hujan sebagai besaran dalam perhitungan untuk mendapatkan debit banjir rencana. Data intensitas curah hujan ini dapat diperoleh dari hasil pencatatan alat ukur hujan otomatis. Data curah hujan yang ada dari tahun-tahun sebelumnya merupakan data yang sangat penting karena dapat digunakan sebagai analisis intensitas curah hujan.

Beberapa peneliti terdahulu telah menerapkan beberapa metode dalam mengestimasi intensitas hujan di berbagai negara dan lokasi. Estimasi intensitas hujan di Kupwara-India menghasilkan bahwa metode yang sesuai adalah distribusi hujan Pearson Tipe III (Dar, Maqbool, and Raazia 2016). Penerapan metode Talbot, Bernard, Kimijima, dan Sherman dilakukan oleh di wilayah Jepang serta pada daerah monsoon Vietnam dimana hasil penelitian menunjukkan bahwa metode Kimijima dan Sherman memiliki kesesuaian pada lokasi studi (Nhat, Tachikawa, and Takara 2006). GutierrezLopez et al. (2019) meneliti penggunaan rumus Sherman untuk menentukan nilai intensitas hujan dari data hujan dengan durasi 5, 10, 15, dan 20 menit di wilayah Mexico dimana hasil penelitian menunjukkan bahwa nilai intensitas hujan bervariasi pada berbagai variasi nilai koefisien C. Lebih jauh hasil penelitian menunjukkan bahwa koefisien C pada rumus Sherman perlu dilakukan penyesuaian untuk bisa digunakan pada wilayah studi. Wambua (2019) melakukan pengembangan kurva Intensitas Durasi Frekuensi (IDF) di wilayah hulu DAS Tana di Kenya dimana hasil penelitian menunjukkan bahwa statistika regresi linier dapat digunakan untuk estimasi persamaan kurva IDF dengan keandalan yang memadai. Penerapan statistika distribusi frekuensi untuk mengestimasi kurva IDF dilakukan di DAS Markandeya Belagavi, Karnataka, India dengan masukan hujan dengan berbagai durasi dan kala ulang dimana hasil penelitian menunjukkan distribusi normal memiliki kesesuaian yang baik untuk menggambarkan karakteristik IDF di lokasi studi (Inayathulla, Rafi, and Engineering 2019).

Penelitian yang sama dilakukan oleh Vanitha and Ravikumar (2017) di wilayah Kumulur di India menunjukkan bahwa distribusi Gumbel lebih cocok untuk digunakan untuk perkiraan kurva IDF. Tfwala et al. (2017) memperkirakan intensitas hujan dan ketidakpastiannya pada batas bawah dan atas untuk durasi hujan 0.125, 0.25, 0.5, 1, 2, 4, dan 6 jam dan kala ulang 2, 10, 25, 50 dan 100 tahun pada wilayah Ghaap plateau, Provinsi Cape, Afrika Selatan menggunakan Generalized Extreme Value (GEV) distribusi. Dalam penelitian yang lain, Ghazavi et al (2017) melakukan perbandingan antara metode Sherman dan Ghahreman-Abkhezr dalam mengestimasi intensitas hujan untuk digunakan sebagai masukan untuk analisis perhitungan debit limpasan pada berbagai kala ulang, dimana metode Ghahreman-Abkhezr menunjukkan hasil yang lebih baik dalam menentukan intensitas hujan. Perbandingan beberapa metode distribusi frekuensi dalam mengestimasi kurva IDF dilakukan David et al. (2019) dimana distribusi Log Pearson terbukti memiliki akurasi yang baik dibandingkan distribusi yang lain sedangkan Jahnvi et al. (2014) membuktikan bahwa distribusi Gumbel lebih tepat digunakan untuk estimasi intensitas hujan di DAS Bhadar, wilayah Gujarat, India.

Penelitian ini menerapkan beberapa metode intensitas hujan yaitu metode Talbot, Mononobe, Hasper Der Weduwen, dan Van Breen untuk mengestimasi intensitas hujan dimana analisis perbandingan akan dilakukan diantara metode-metode tersebut untuk menentukan metode mana yang memiliki keandalan dalam memperkirakan intensitas hujan pada lokasi studi. Lebih jauh, penelitian ini juga menghasilkan kurva Intensitas Durasi Frekuensi (IDF) pada berbagai kala ulang $2,5,10,20$, dan 25 tahun, dimana penentuan akurasi metode kurva IDF dilakukan untuk kala ulang 2 dan 5 tahun dengan mempertimbangkan tingkat penerapan praktis dari kedua besaran kala ulang tersebut.

\section{Material dan Metode}

Lokasi penelitian yang digunakan adalah Stasiun Hujan Jabung yang termasuk dalam wilayah Sub DAS Amprong (Sub DAS luas $609.26 \mathrm{~km}^{2}$ dan panjang sungai $43.02 \mathrm{~km}$ ). Secara administratif Sub DAS Amprong terletak pada wilayah Kota Malang dan Kabupaten Malang. Selengkapnya lokasi studi dapat dilihat pada Gambar 1, sedangkan tahapan prosedur pengerjaan dalam studi ini disajikan pada Gambar 2. Data-data penting yang dibutuhkan dalam studi ini meliputi data peta administrasi lokasi, data hujan dan koordinat lokasi stasiun hujan. Data hujan yang digunakan dalam studi ini 
meliputi data curah hujan harian maksimum dan data curah hujan jam-jaman yang diperoleh dari stasiun hujan Jabung dalam rentang periode pengukuran 2011-2017.

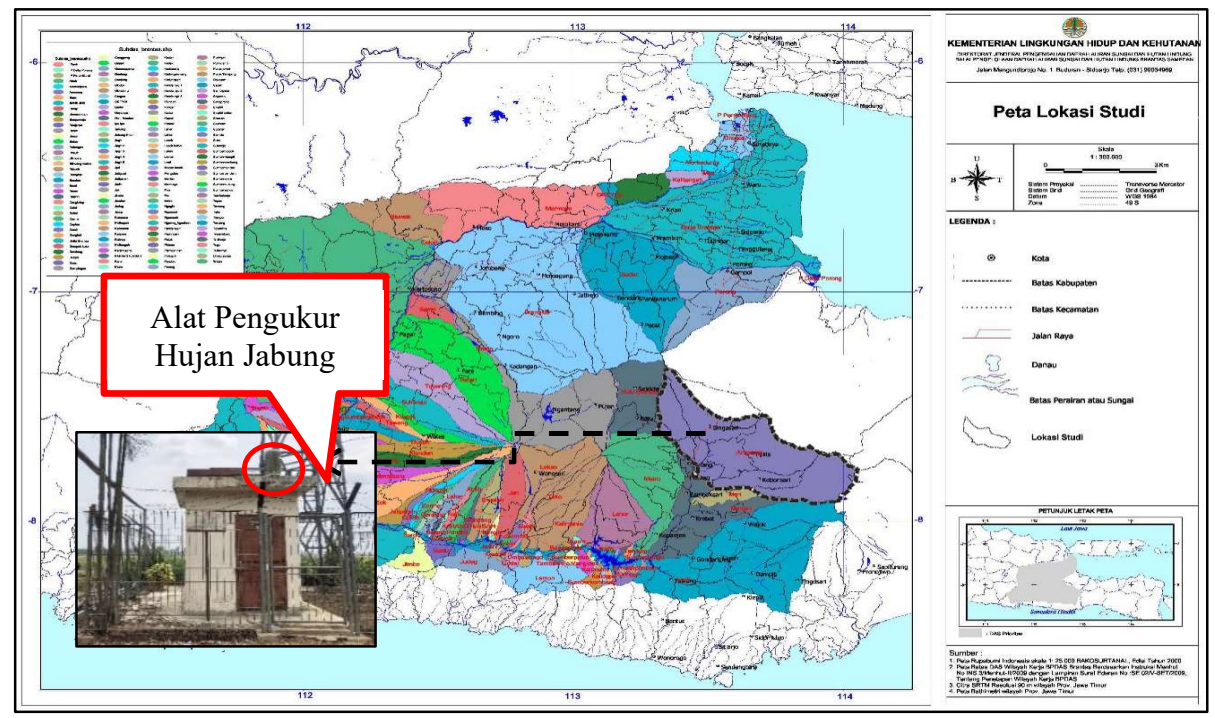

Gambar 1. Peta lokasi studi beserta stasiun hujan yang digunakan

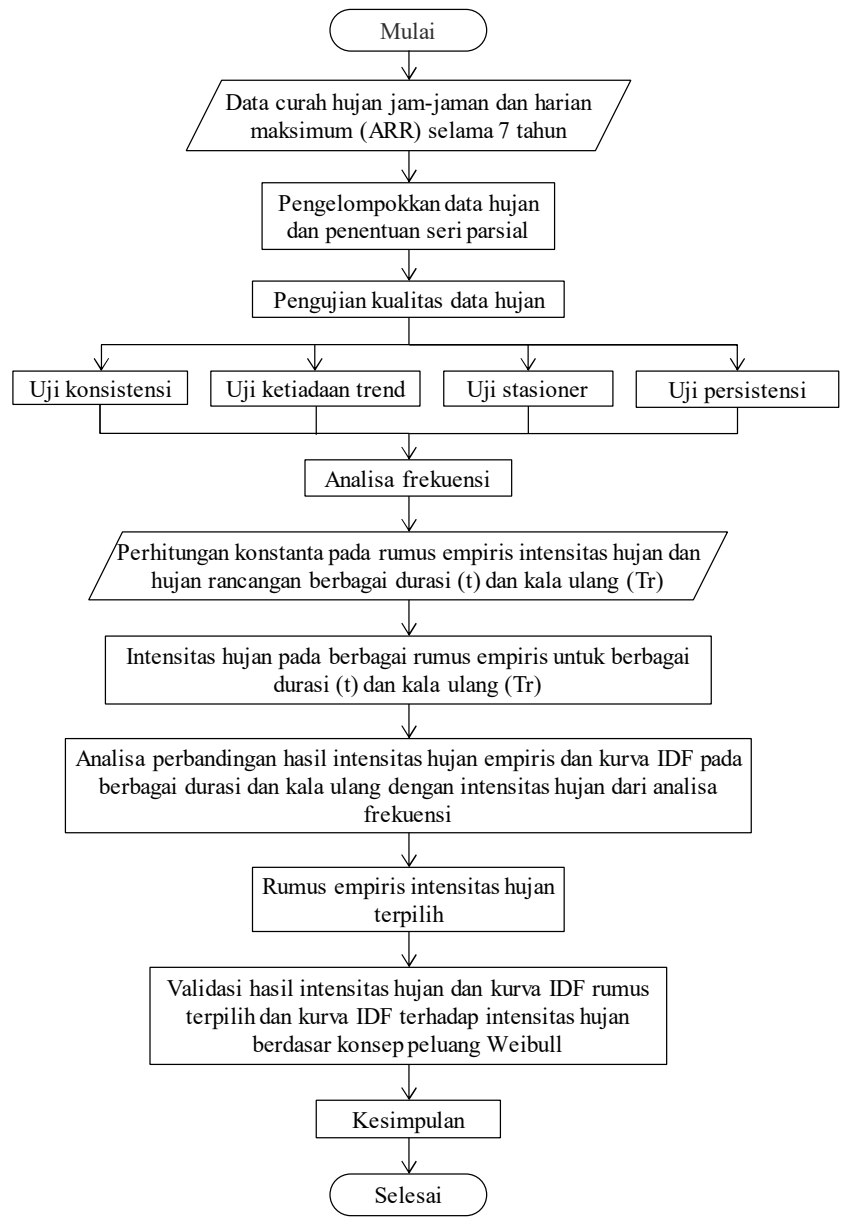

Gambar 2. Tahapan analisis dalam studi 


\subsection{Tahapan studi}

Tahapan analisis dalam studi ini dapat dijelaskan sebagai berikut:

1. Pengumpulan data hujan jam-jaman dan hujan harian maksimum selama periode 2011-2017 dari stasiun Jabung.

2. Pengelompokan data intensitas hujan $(I)$ berdasarkan lamanya curah hujan (durasi, $t$ ).

3. Penentuan batas bawah dari data hujan jam-jaman maksimum tahunan setiap durasi untuk memperbanyak data perhitungan dengan menggunakan pendekatan seri parsial (partial series) (Montesarchio et al. 2015).

4. Pengujian outlier data hujan untuk mengidentifikasi nilai-nilai data hujan yang memiliki besaran diluar batas nilai normal maksimum dan minimum yang diijinkan (Cohn et al. 2013).

5. Pengujian kualitas data hujan dengan menggunakan pendekatan statistika meliputi uji konsistensi data Rescaled Adjusted Partial Sums (RAPS) (Rangsiwanichpong, Kazama, and Ekkawatpanit 2017), uji ketiadaan trend (Salman et al. 2018), uji stasioner (De Paola et al. 2018), dan uji persistensi (Roghani, Soltani, and Bashari 2016).

6. Perhitungan intensitas hujan pada berbagai durasi hujan $(t)$ dan kala ulang $(T r)$ dengan menggunakan pendekatan analisis frekuensi Gumbel dan Log Pearson III (Bhat et al. 2019).

7. Pengujian kesesuaian distribusi frekuensi dengan menggunakan uji kesesuaian Chi-Square dan Smirnov-Kolmogorov.

8. Perhitungan nilai konstanta yang terdapat dalam persamaan intensitas hujan (Talbot, Mononobe, Hasper Der Weduwen dan Van Breen).

9. Perhitungan intensitas hujan dengan menggunakan metode Talbot, Mononobe, Hasper Der Weduwen dan Van Breen dalam berbagai kala ulang untuk setiap durasi hujan.

10. Perbandingan kurva Intensitas Durasi Frekuensi (IDF) antara intensitas hujan pengamatan dan intensitas hujan metode empiris Talbot, Mononobe, Hasper Der Weduwen dan Van Breen). Kurva IDF digambarkan dalam berbagai kala ulang dan metode.

\subsection{Rumus intensitas hujan}

Intensitas curah hujan merupakan tinggi hujan persatuan waktu yang dinyatakan dalam $\mathrm{mm} / \mathrm{jam}$ Nilai intensitas hujan memiliki besaran yang bervariasi tergantung lamanya hujan (durasi, $t$ ) dan frekuensi atau kala ulang $(T r)$ yang ditinjau. Beberapa rumus intensitas hujan yang digunakan dalam studi ini meliputi:

1. Intensitas dari hujan pengamatan

Masukan utama dalam perhitungan intensitas hujan pengamatan adalah data hujan jam-jaman. Persamaan yang digunakan untuk menghitung intensitas hujan pengamatan adalah (Subyani and Al-Amri 2015) :

$$
I=\frac{R}{t}
$$

dengan $I=$ intensitas curah hujan (mm/jam), $t=$ lamanya curah hujan (jam), $R=$ tinggi hujan $(\mathrm{mm})$.

\section{Metode Talbot}

Rumus ini dikembangkan oleh Prof. Talbot pada tahun 1881 dan banyak digunakan karena kemudahan dimana nilai konstanta a dan $b$ pada rumus harus ditentukan terlenih dahulu (Asbintari, Rismalinda, and Alfi 2016). Adapun persamaan Talbot disajikan sebagai berikut:

$$
I=\frac{a}{t+b}
$$

dengan $I=$ intensitas curah hujan $(\mathrm{mm} / \mathrm{jam}), t=$ lamanya hujan (jam), $a, b=$ konstanta yang tergantung pada lamanya curah hujan. 


\section{Metode Mononobe}

Rumus Mononobe yang merupakan variasi dari rumus Talbot, Sherman, dan Ishiguro yang merupakan rumus intensitas curah hujan untuk curah hujan jangka pendek (Suharyanto 2016). Persamaan Mononobe dapat dijelaskan sebagai berikut:

$$
I=\frac{R_{24}}{24}\left(\frac{24}{t}\right)^{m}
$$

dengan $I=$ intensitas curah hujan $(\mathrm{mm} / \mathrm{jam}), R_{24}=$ curah hujan harian maksimum dalam 24 jam (mm), $t=$ lamanya curah hujan (jam), dan $m=$ konstanta $(0,667)$.

4. Metode Hasper Der Weduwen

Metode ini merupakan hasil dari penelitian yang dilakukkan oleh Hasper dan Der Weduwen di Indonesia. Penurunan rumus diperoleh dari kecenderungan curah hujan harian yang dikelompokkan atas dasar anggapan bahwa curah hujan memiliki distribusi yang simetris dengan durasi curah hujan lebih kecil dari 1 jam dan durasi curah hujan dari 1 sampai 24 jam (Susilowati 2012). Persamaan rumus Haspers Der Weduwen disajikan sebagai berikut:

- Untuk $0<t \leqslant 1$ jam

$$
R=\sqrt{\frac{11300}{t+3,12}} \times\left[\frac{R i}{100}\right]
$$

- Untuk $0<t \leqslant 24$ jam

$$
R=\sqrt{\frac{11300}{t+3,12}} \times\left[\frac{X i}{100}\right]
$$

di mana

$$
R i=X i\left(\frac{1218 t+54}{X i(1-t)+1272 t}\right)
$$

dengan $I=$ intensitas curah hujan (mm/jam), $t=$ lamanya curah hujan (jam), $R=$ curah hujan Hasper Der Weduwen, dan $X i=$ curah hujan harian maksimum yang terpilih ( $\mathrm{mm} / \mathrm{hari})$.

\section{Metode Van Breen}

Penurunan rumus yang dilakukan oleh Van Breen di Indonesia didasarkan atas anggapan bahwa lamanya durasi hujan yang terjadi di Pulau Jawa adalah selama 4 jam dengan hujan efektif sebesar $90 \%$ dari jumlah curah hujan selama 24 jam (Hendri 2015). Adapun rumus Van Breen dapat dilihat sebagai berikut:

$$
I_{T}=\frac{54 R_{T}+0,007 R_{T}^{2}}{t_{c}+0,3 R_{T}}
$$

dengan $I_{T}=$ intensitas curah hujan pada suatu periode ulang $(\mathrm{mm} / \mathrm{jam}), R_{24}=$ curah hujan harian maksimum pada suatu periode ulang ( $\mathrm{mm} / \mathrm{hari})$, dan $t c=$ waktu konsentrasi (menit).

\subsection{Intensitas Durasi Frekuensi (IDF)}

Intensitas curah hujan secara umum berhubungan dengan kejadian dan lamanya hujan disebut dengan Intensitas Durasi Frekuensi. Analisis dan desain hidrologi tidak hanya memerlukan volume atau ketinggian hujan akan tetapi juga distribusi hujan terhadap tempat dan waktu. Intensitas Durasi Frekuensi (IDF) merupakan hubungan empiris antara intensitas hujan, durasi hujan dan frekuensi atau kala ulang. Kurva IDF terdiri dari tiga parameter dimana intensitas hujan sebagai ordinat (sumbu 
$y$ ), durasi hujan sebagai absis (sumbu $x$ ), dan kala ulang sebagai parameter ketiga (Harisuseno and Bisri 2017; Limantara, Harisuseno, and Dewi 2018).

\section{Hasil dan Pembahasan}

Dalam studi ini, pendekatan distribusi Log Pearson Tipe III digunakan untuk memperkirakan nilai intensitas hujan pada berbagai kala ulang $(T r)$ dan durasi hujan $(t)$ (Bhat et al. 2019), sedangkan kala ulang yang digunakan dalam studi meliputi kala ulang 2, 5, 10, dan 25 tahun (Zope et al. 2016). Dalam studi ini, nilai intensitas hujan dari rumus empiris dibandingkan dengan nilai intensitas hujan rancangan yang dihasilkan berdasarkan pendekatan analisis frekuensi Log Pearson Tipe III. Hasil analisis frekuensi ini akan digunakan sebagai pembanding dan sebagai dasar dalam perhitungan tetapan-tetapan metode intensitas hujan empiris.

Tabel 1 menyajikan rekapitulasi hasil intensitas hujan rancangan pada berbagai durasi hujan $(t)$ dan kala ulang $(T r)$. Berdasarkan Tabel 1, dapat dilihat bahwa nilai intensitas hujan menunjukkan kecenderungan meningkat dengan semakin besarnya kala ulang yang ditinjau serta semakin singkatnya durasi hujan. Hasil ini menegaskan hasil penelitian yang dilakukan oleh Akpen, Aho, and Musa (2019) yang menyatakan bahwa semakin singkat periode terjadinya hujan akan memberikan dampak semakin besar intensitas hujan yang terjadi. Dengan demikian, dapat dipahami bahwa kejadian hujan dengan intensitas hujan tinggi terjadi pada durasi hujan yang singkat dan kala ulang. Berdasarkan hasil pada Tabel 1, maka dapat ditentukan konstanta-konstanta empiris pada berbagai rumus empiris intensitas hujan yang ditinjau. Selanjutnya nilai perkiraan konstanta-konstanta masing-masing rumus empiris digunakan untuk mengestimasi nilai intensitas hujan empiris. Hasil perhitungan intensitas hujan pada berbagai durasi hujan dan besar kala ulang untuk masing-masing rumus empiris Talbot, Mononobe, Hasper Der Weduwen, dan Van Breen disajikan pada Tabel 2 hingga Tabel 5. Berdasarkan hasil perhitungan intensitas hujan rumus empiris seperti yang ditunjukkan pada Tabel 2 - Tabel 5, maka dapat disimpulkan bahwa jika semakin lama durasi hujan yang terjadi akan menghasilkan intensitas hujan yang semakin kecil dan dilihat dari semakin besar kala ulang yang digunakan maka intensitas hujan yang dihasilkan semakin besar. Hal tersebut berlaku untuk semua metode intensitas hujan yang digunakan dalam penelitian ini.

Tabel 1. Rekapitulasi intensitas hujan rancangan berbagai kala ulang $(\operatorname{Tr})$ dan durasi $(t)$ berdasarkan analisis frekuensi

\begin{tabular}{cccccc}
\hline \multirow{2}{*}{$\begin{array}{c}\text { Durasi, } t \\
\text { (menit) }\end{array}$} & \multicolumn{5}{c}{ Intensitas hujan rancangan (mm/jam) } \\
\cline { 2 - 6 } & 2 th & 5 th & 10 th & 20 th & 25 th \\
\hline 60 & 28.87 & 40.82 & 49.13 & 57.38 & 60.05 \\
120 & 17.83 & 25.37 & 31.12 & 37.22 & 39.29 \\
180 & 12.97 & 17.51 & 20.94 & 24.57 & 25.79 \\
240 & 11.37 & 15.61 & 18.62 & 21.65 & 22.64 \\
300 & 4.96 & 8.62 & 11.99 & 16.09 & 17.59 \\
\hline
\end{tabular}

Tabel 2. Rekapitulasi intensitas hujan rancangan berbagai kala ulang $(T r)$ dan durasi $(t)$ berdasarkan rumus Talbot

\begin{tabular}{cccccc}
\hline \multirow{2}{*}{$\begin{array}{c}\text { Durasi, } t \\
\text { (menit) }\end{array}$} & \multicolumn{5}{c}{ Kala ulang (Tr) } \\
\cline { 2 - 6 } & 2 th & 5 th & 10 th & 20 th & 25 th \\
\hline 60 & 33.24 & 43.73 & 51.01 & 58.38 & 60.82 \\
120 & 17.29 & 24.55 & 30.06 & 35.90 & 37.88 \\
180 & 11.68 & 17.07 & 21.31 & 25.92 & 27.51 \\
240 & 8.82 & 13.08 & 16.50 & 20.28 & 21.59 \\
300 & 7.08 & 10.60 & 13.46 & 16.66 & 17.77 \\
\hline
\end{tabular}


Tabel 3. Rekapitulasi intensitas hujan rancangan berbagai kala ulang (Tr) dan durasi (t) berdasarkan rumus Mononobe

\begin{tabular}{cccccc}
\hline \multirow{2}{*}{$\begin{array}{c}\text { Durasi, } t \\
\text { (menit) }\end{array}$} & \multicolumn{5}{c}{ Kala Ulang $($ Tr $)$} \\
\cline { 2 - 6 } & 2 th & 5 th & 10 th & 20 th & 25 th \\
\hline 60 & 16.69 & 22.68 & 26.92 & 31.20 & 32.61 \\
120 & 10.52 & 14.29 & 16.96 & 19.66 & 20.54 \\
180 & 8.02 & 10.90 & 12.94 & 15.00 & 15.68 \\
240 & 6.62 & 9.00 & 10.68 & 12.38 & 12.94 \\
300 & 5.71 & 7.76 & 9.21 & 10.67 & 11.15 \\
\hline
\end{tabular}

Tabel 4. Rekapitulasi intensitas hujan rancangan berbagai kala ulang (Tr) dan durasi (t) berdasarkan rumus Haspers Der Weduwen

\begin{tabular}{cccccc}
\hline \multirow{2}{*}{$\begin{array}{c}\text { Durasi, } t \\
\text { (menit) }\end{array}$} & \multicolumn{5}{c}{ I-Hasper Der Weduwen (mm/jam) } \\
\cline { 2 - 6 } & 2 th & 5 th & 10 th & 20 th & 25 th \\
\hline 60 & 25.22 & 34.26 & 40.67 & 47.14 & 49.26 \\
120 & 15.96 & 21.83 & 26.04 & 30.34 & 31.76 \\
180 & 11.91 & 16.33 & 19.51 & 22.77 & 23.85 \\
240 & 9.56 & 13.12 & 15.69 & 18.33 & 19.20 \\
300 & 8.00 & 11.00 & 13.16 & 15.38 & 16.11 \\
\hline
\end{tabular}

Tabel 5. Rekapitulasi intensitas hujan rancangan berbagai kala ulang $(\operatorname{Tr})$ dan durasi ( $t)$ berdasarkan rumus Van Breen

\begin{tabular}{cccccc}
\hline \multirow{2}{*}{$\begin{array}{c}\text { Durasi, } t \\
\text { (menit) }\end{array}$} & \multicolumn{5}{c}{ Kala Ulang $($ Tr $)$} \\
\cline { 2 - 6 } & 2 th & 5 th & 10 th & 20 th & 25 th \\
\hline 60 & 34.92 & 44.38 & 50.38 & 55.94 & 57.66 \\
120 & 19.39 & 25.40 & 29.40 & 33.25 & 34.47 \\
180 & 13.42 & 17.79 & 20.76 & 23.65 & 24.58 \\
240 & 10.26 & 13.69 & 16.04 & 18.35 & 19.10 \\
300 & 8.31 & 11.12 & 13.07 & 15.00 & 15.62 \\
\hline
\end{tabular}

\subsection{Kurva Intensitas Durasi Frekuensi (IDF)}

Kurva Intensitas Durasi Frekuensi $(I D F)$ diperoleh dengan menggambar nilai variasi intensitas hujan (I) pada berbagai durasi hujan $(t)$ dan kala ulang $(T r)$. Berdasarkan kurva Intensitas Durasi Frekuensi $(I D F)$ maka dapat dengan mudah ditentukan nilai intensitas hujan (I) yang diinginkan untuk melakukan desain bangunan air dengan debit banjir rancangan pada kala ulang tertentu. Berdasarkan hasil perhitungan intensitas hujan yang telah dilakukan pada berbagai kala ulang $(T r)$ dan durasi hujan $(t)$ untuk semua rumus empiris yang ditinjau, maka dilakukan penggambaran kurva Intensitas Durasi Frekuensi $(I D F)$. Penggambaran kurva Intensitas Durasi Frekuensi $(I D F)$ juga dilakukan untuk intensitas hujan berbagai durasi hujan dan kala ulang yang diperoleh dari perhitungan analisis frekuensi Log Pearson Tipe III. Dengan menggambarkan kurva Intensitas Durasi Frekuensi $(I D F)$ semua rumus empiris dan hasil analisis frekuensi Log Pearson Tipe III dalam satu grafik, maka analisis perbandingan dapat dilakukan dengan mudah. Hasil penggambaran kurva Intensitas Durasi Frekuensi (IDF) untuk semua rumus empiris dan Log Pearson Tipe III dapat dilihat pada Gambar 3 hingga Gambar 7. 


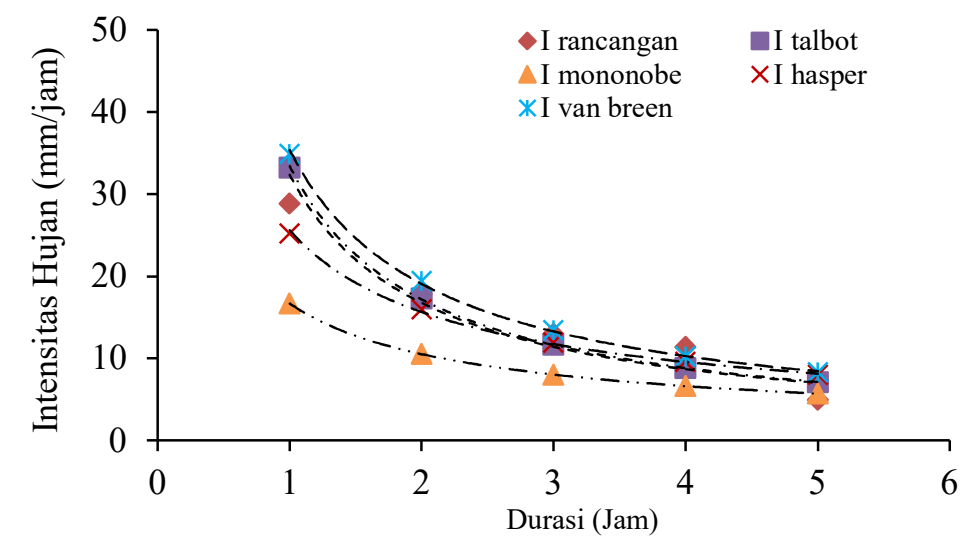

Gambar 3. Kurva $I D F$ Intensitas Hujan Rancangan dengan Intensitas Hujan Metode Empiris Kala Ulang 2 Tahun

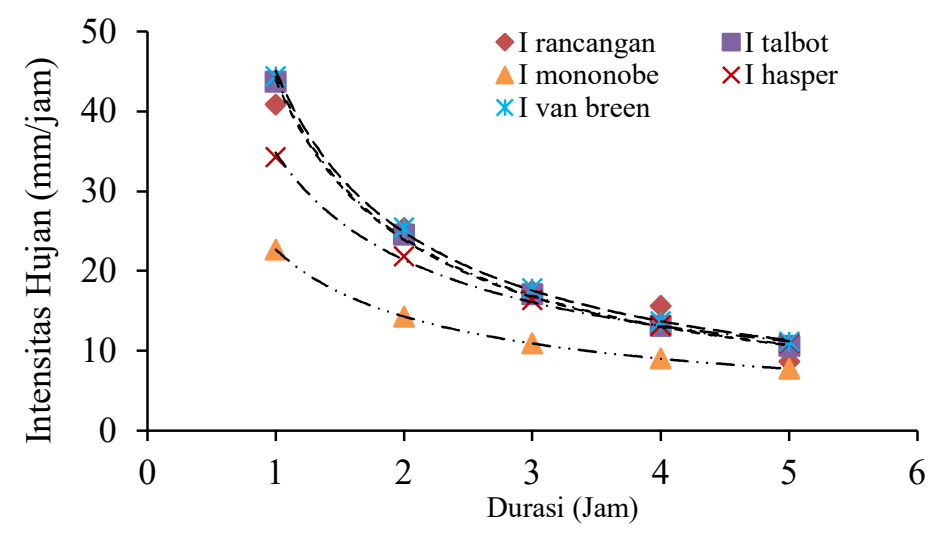

Gambar 4. Kurva $I D F$ Intensitas Hujan Rancangan dengan Intensitas Hujan Metode Empiris Kala Ulang 5 Tahun

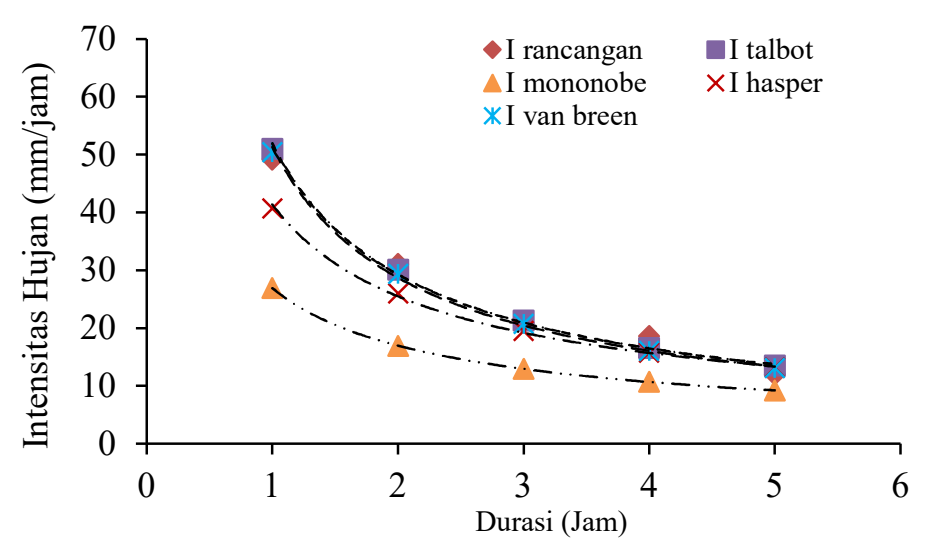

Gambar 5. Kurva $I D F$ Intensitas Hujan Rancangan dengan Intensitas Hujan Metode Empiris Kala Ulang 10 Tahun 


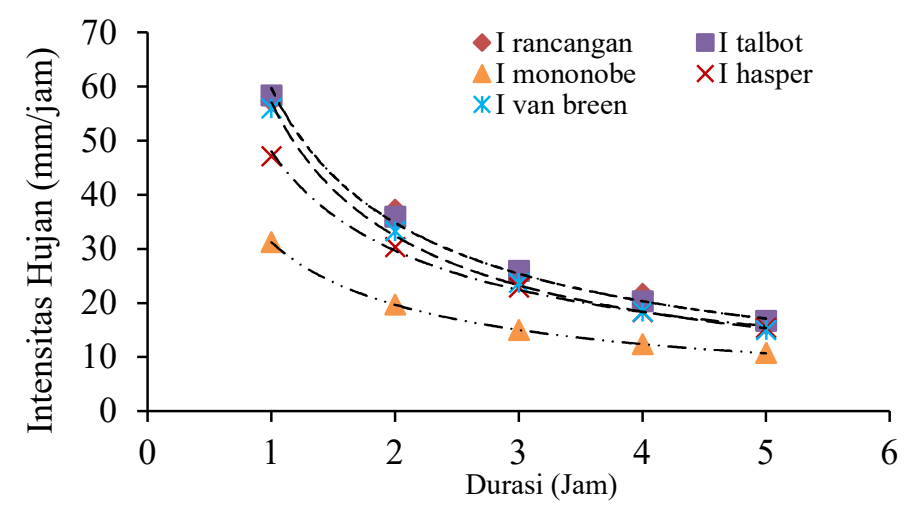

Gambar 6. Kurva IDF Intensitas Hujan Rancangan dengan Intensitas Hujan Metode Empiris Kala Ulang 20 Tahun

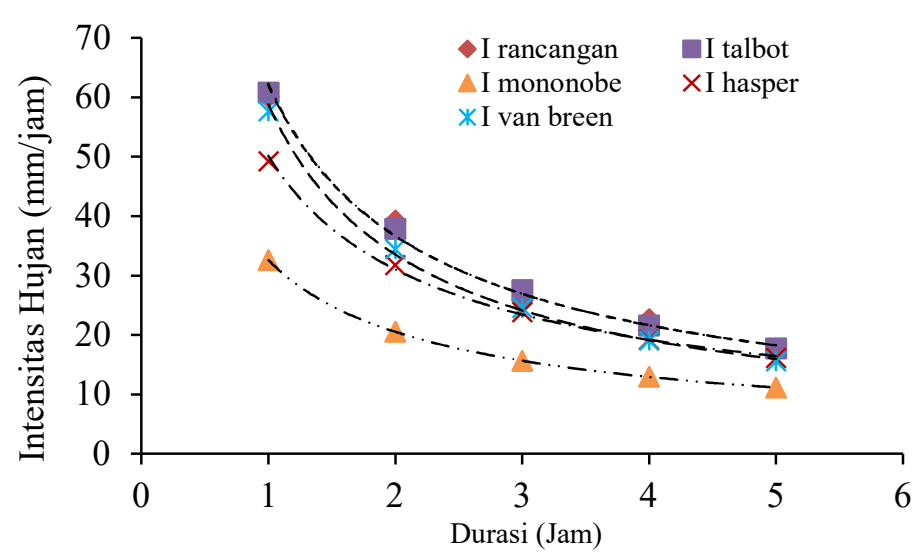

Gambar 7. Kurva $I D F$ Intensitas Hujan Rancangan dengan Intensitas Hujan Metode Empiris Kala Ulang 25 Tahun

Pada Gambar 3 - Gambar 7 kurva IDF intensitas hujan rancangan dan intensitas hujan metode empiris dalam berbagai kala ulang dapat disimpulkan bahwa semakin besar kala ulang akan menghasilkan penyimpangan yang semakin besar pada setiap metode intensitas hujan empiris dan intensitas hujan rancangan, dan semakin panjang durasi yang digunakan akan menghasilkan intensitas hujan yang semakin kecil pula. Karakteristik kurva Intensitas Durasi Frekuensi (IDF) yang dihasilkan memiliki kesamaan dengan hasil penelitian dari Wagesho and Claire (2016) dimana diperoleh pola bahwa intensitas hujan dari rumus empiris memiliki kecenderungan untuk menyimpang pada besaran kala ulang yang besar.

\subsection{Analisis Kesesuaian Intensitas Hujan Metode Empiris}

Penentuan intensitas hujan metode empiris yang sesuai dengan lokasi penelitian dilakukan dengan perhitungan berikut ini.

a. Deviasi Rata-rata

Intensitas hujan metode empiris yang dibandingkan dengan intensitas hujan rancangan dengan menghasilkan nilai deviasi rata-rata terkecil merupakan metode empiris yang paling baik dan sesuai untuk diterapkan di lokasi penelitian. Hasil perhitungan deviasi rata-rata diperlihatkan pada Tabel 6 . Dari tabel ini dapat disimpulkan bahwa metode Talbot memiliki nilai deviasi berkisar antara 1.03 2.08 dengan nilai rata-rata sebesar 1.49. Nilai ini merupakan yang terkecil dibandingkan dengan hasil rumus-rumus empiris lainnya. 
b. Kesalahan Relatif $(\mathrm{Kr})(\%)$

Intensitas hujan metode empiris yang dibandingkan dengan intensitas hujan rancangan dengan menghasilkan nilai kesalahan relatif rata-rata terkecil merupakan metode empiris yang paling baik dan sesuai untuk diterapkan dilokasi penelitian, seperti yang ditunjukkan pada Tabel 7. Hasil perhitungan kesalahan relatif rata-rata pada Tabel 7 disimpulkan bahwa metode Talbot memiliki nilai kesalahan relatif $(K R)$ dalam rentang 3.44 - 18.68 dengan nilai rata-rata sebesar 8.64\%.

c. Koefisien Nash Sutcliffe (ENS)

Intensitas hujan metode empiris yang dibandingkan dengan intensitas hujan rancangan dengan menghasilkan nilai ENS mendekati $1(0<E N S<1)$ merupakan metode empiris yang paling baik dan sesuai untuk diterapkan dilokasi penelitian. Pada Tabel 8 dapat disimpulkan bahwa metode Talbot memiliki nilai koefisien Nash Sutcliffe (ENS) yang paling mendekati nilai 1 sebesar 0.975 .

Berdasarkan hasil analisis kesesuaian metode intensitas hujan pada Stasiun Jabung didapatkan bahwa Metode Talbot yang paling sesuai diterapkan pada lokasi penelitian karena memiliki nilai deviasi rata-rata dan kesalahan relatif rata-rata terkecil dan nilai rata-rata koefisien Nash Sutcliffe $(E N S)$ yang paling mendekati nilai 1 yang masuk kedalam kategori baik $(0<E N S<1)$.

Tabel 6. Rekapitulasi nilai deviasi rata-rata masing-masing rumus empiris pada berbagai kala ulang

\begin{tabular}{ccccc}
\hline Kala Ulang & \multicolumn{4}{c}{ Deviasi Rata-rata } \\
\cline { 2 - 5 }$(T r)$ & $I$-Talbot & $I$-Mononobe & $I$-Hasper & $I$-Van Breen \\
\hline 2 & 2.18 & 5.99 & 2.29 & 2.50 \\
5 & 1.74 & 8.66 & 3.23 & 1.66 \\
10 & 1.38 & 11.02 & 3.81 & 1.36 \\
20 & 1.12 & 13.60 & 4.59 & 2.14 \\
25 & 1.03 & 14.49 & 5.03 & 2.79 \\
\hline Rerata & 1.49 & 10.75 & 3.79 & 2.09 \\
\hline
\end{tabular}

Tabel 7. Rekapitulasi nilai kesalahan relatif masing-masing rumus empiris pada berbagai kala ulang

\begin{tabular}{ccccc}
\hline \multirow{2}{*}{ Kala } & \multicolumn{4}{c}{ Kesalahan Relatif $(K R),(\%)$} \\
\cline { 2 - 5 } Ulang $(\operatorname{Tr})$ & $I$-Talbot & $I$-Mononobe & $I$-Hasper & $I$-Van Breen \\
\hline 2 & 18.68 & 35.63 & 21.73 & 22.09 \\
5 & 10.41 & 35.66 & 16.05 & 10.34 \\
10 & 6.53 & 38.95 & 13.16 & 6.36 \\
20 & 4.14 & 41.64 & 12.67 & 7.78 \\
25 & 3.44 & 42.41 & 13.65 & 9.55 \\
\hline Rerata & 8.64 & 38.86 & 15.45 & 11.23 \\
\hline
\end{tabular}

Tabel 8. Rekapitulasi nilai koefisien Nash Sutcliffe masing-masing rumus empiris pada berbagai kala ulang

\begin{tabular}{ccccc}
\hline Kala Ulang & \multicolumn{4}{c}{ Koefisien Nash Sutcliffe (ENS) } \\
\cline { 2 - 5 }$(T r)$ & $I$-Talbot & $I$-Mononobe & I-Hasper & $I$-Van breen \\
\hline 2 & 0.929 & -0.042 & 0.844 & 0.89 \\
5 & 0.972 & -0.042 & 0.815 & 0.97 \\
10 & 0.987 & -0.024 & 0.798 & 0.99 \\
20 & 0.994 & -0.004 & 0.777 & 0.97 \\
25 & 0.994 & 0.002 & 0.770 & 0.96 \\
\hline Rerata & 0.975 & -0.022 & 0.801 & 0.96 \\
\hline
\end{tabular}




\subsection{Analisis validasi rumus intensitas hujan terpilih}

Analisis validasi bertujuan mengetahui sejauh mana kesesuaian nilai intensitas hujan yang dihasilkan oleh rumus empiris terpilih jika dibandingkan dengan hasil intensitas hujan pengamatan berdasarkan konsep peluang dan kala ulang $(T r)$. Perbandingan intensitas hujan yang dihasilkan oleh rumus empiris dilakukan pada berbagai kala ulang. Dalam studi ini, nilai kala ulang yang dipertimbangkan dalam analisis validasi memiliki besaran kala ulang 2 dan 5 tahun. Pemilihan kala ulang 2 dan 5 tahun ini dilakukan dengan mempertimbangkan jumlah data hujan historis yang tersedia serta kebutuhan praktis dalam perencanaan saluran drainase di wilayah perkotaan. Tabel 9 menyajikan intensitas hujan yang dihasilkan dari rumus Talbot dengan intensitas hujan pengamatan dari konsep peluang dan kala ulang. Analisis validasi rumus intensitas hujan Talbot dilakukan dengan membandingkan nilai intensitas hujan dengan intensitas hujan pengamatan dimana analisis kuantitatif dilakukan untuk menentukan kualitas hasil validasi dari rumus Talbot. Tabel 10 menunjukkan perhitungan deviasi rata-rata, kesalahan relatif (\%) dan koefisien Nash Sutcliffe (ENS) hasil validasi rumus Talbot dengan intensitas hujan pengamatan berdasarkan konsep peluang dan kala ulang.

Dari hasil perhitungan Tabel 10 dapat disimpulkan bahwa nilai deviasi rata-rata dan kesalahan relatif rata-rata intensitas metode empiris terpilih yaitu metode Talbot menghasilkan nilai yang lebih besar yaitu 2.22 untuk deviasi rata-rata dan $15.11 \%$ untuk kesalahan relatif rata-rata, dan nilai ENS sebesar 0.93 yang masih termasuk kategori baik mendekati 1. Jika dilihat dari hasil perhitungan dimana intensitas hujan metode empiris dibandingkan dengan intensitas hujan rancangan didapatkan hasil perhitungan intensitas hujan metode terpilih memiliki nilai-nilai yang lebih besar.

Kurva $I D F$ metode intensitas hujan terpilih yaitu metode Talbot dengan kala ulang 2 dan 5 tahun dapat dilihat pada Gambar 8 dan Gambar 9. Dapat dilihat bahwa jika semakin besar kala ulang yang digunakan menghasilkan penyimpangan yang semakin besar. Sedangkan jika dilihat dari durasi yang digunakan dapat disimpulkan bahwa semakin panjang durasi yang digunakan menghasilkan intensitas hujan yang semakin kecil, baik dilihat dari intensitas hujan pengamatan ataupun intensitas hujan metode empiris terpilih (metode Talbot), hasil perhitungan ini dapat dilihat pada Tabel 9. Kurva $I D F$ metode intensitas hujan terpilih yaitu metode Talbot dengan kala ulang 2 dan 5 tahun dapat dilihat pada Gambar 8 dan Gambar 9. Dapat dilihat bahwa jika semakin besar kala ulang yang digunakan menghasilkan penyimpangan yang semakin besar.

Tabel 9. Nilai intensitas hujan rumus empiris Talbot dan intensitas pengamatan berdasarkan konsep peluang dan kala ulang

\begin{tabular}{ccccc}
\hline \multirow{2}{*}{$\begin{array}{c}\text { Durasi, } t \\
\text { (menit) }\end{array}$} & \multicolumn{2}{c}{$\operatorname{Tr} 2$ th } & \multicolumn{2}{c}{$\operatorname{Tr} 5$ th } \\
\cline { 2 - 5 } & $I$-Pengamatan & $I$-Talbot & $I$-Pengamatan & $I$-Talbot \\
\hline 60 & 29 & 33.24 & 43.00 & 43.73 \\
120 & 16.5 & 17.29 & 28.50 & 24.55 \\
180 & 12.7 & 11.68 & 18.00 & 17.07 \\
240 & 11.5 & 8.82 & 18.25 & 13.08 \\
300 & 4.8 & 7.08 & 10.20 & 10.60 \\
\hline
\end{tabular}

Tabel 10. Hasil validasi intensitas hujan rumus empiris Talbot dan intensitas pengamatan berdasarkan konsep peluang dan kala ulang

\begin{tabular}{cccc}
\hline Kala & \multicolumn{3}{c}{$I$-Talbot (mm/jam) } \\
\cline { 2 - 4 } $\begin{array}{c}\text { Ulang } \\
(T r)\end{array}$ & Deviasi & $K r(\%)$ & $E N S$ \\
\hline 2 & 2.20 & 19.62 & 0.93 \\
5 & 2.24 & 10.60 & 0.94 \\
\hline Rerata & 2.22 & 15.11 & 0.93 \\
\hline
\end{tabular}




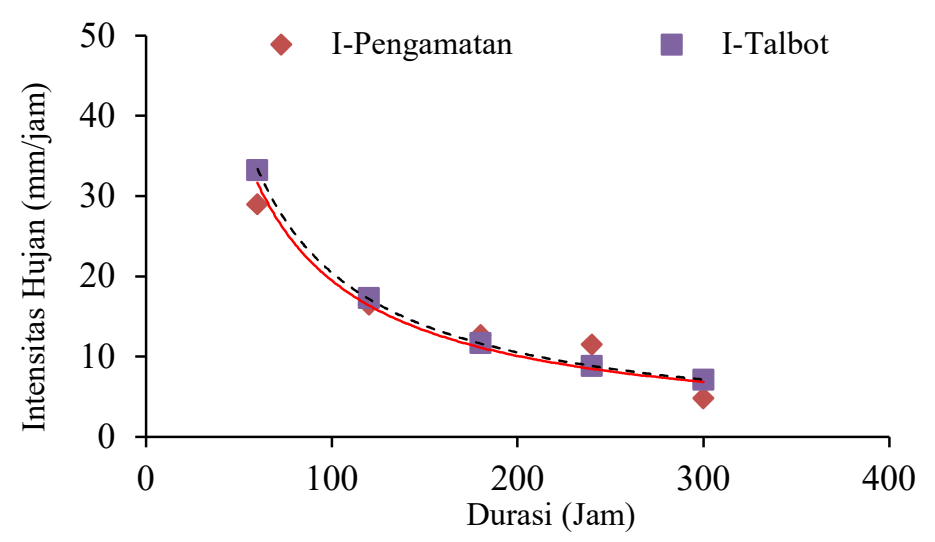

Gambar 8. Kurva $I D F$ rumus intensitas hujan Talbot dan pengamatan untuk kala ulang 2 Tahun

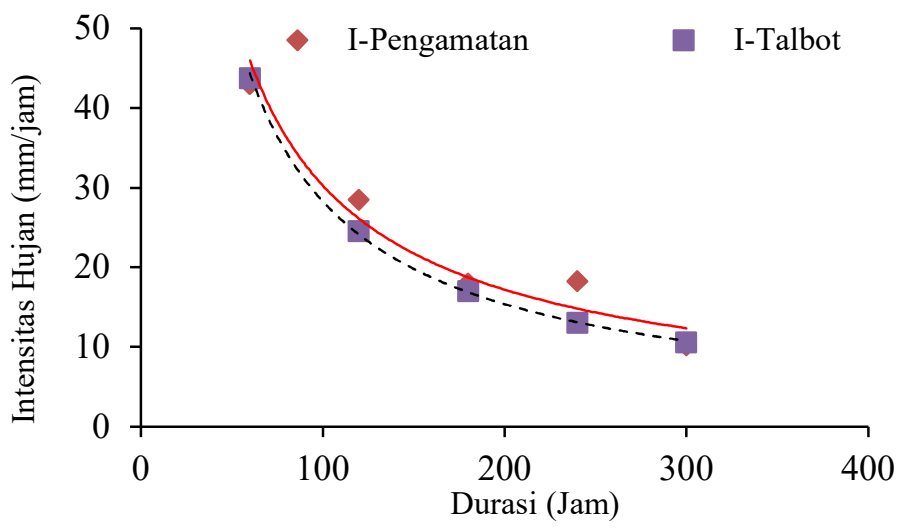

Gambar 9. Kurva $I D F$ rumus intensitas hujan Talbot dan pengamatan untuk kala ulang 5 Tahun

Sedangkan jika dilihat dari durasi yang digunakan dapat disimpulkan bahwa semakin panjang durasi yang digunakan menghasilkan intensitas hujan yang semakin kecil, baik dilihat dari intensitas hujan pengamatan ataupun intensitas hujan metode empiris terpilih (metode Talbot), hasil perhitungan ini dapat dilihat pada Tabel 9.

\section{Kesimpulan}

Berdasarkan hasil analisis intensitas hujan yang telah dilakukan, maka dapat diketahui bahwa pola variasi nilai intensitas hujan yang dihasilkan oleh semua rumus empiris memiliki karakter pola yang mirip dimana nilai intensitas hujan yang tinggi ditunjukkan oleh hujan dengan durasi yang singkat dan kala ulang yang besar. Sebaliknya, nilai intensitas hujan menunjukkan nilai yang kecil untuk kejadian hujan dengan durasi yang panjang dan kala ulang yang kecil. Karakteristik kurva Intensitas Durasi Frekuensi $(I D F)$ yang dihasilkan oleh masing-masing rumus empiris menunjukkan pola yang sama dimana pola grafik $I D F$ mengikuti pola eksponensial. Hasil analisis kesesuaian rumus empiris intensitas hujan dengan intensitas hujan pengamatan menunjukkan bahwa rumus Talbot memiliki keandalan yang baik dalam mengestimasi intensitas hujan di lokasi studi. Hasil tersebut diindikasikan dengan nilai parameter kesalahan relatif relatif dalam rentang $3.44-18.68$ dengan nilai rata-rata sebesar $8.64 \%$, nilai deviasi berkisar antara $1.03-2.08$ dengan nilai rata-rata sebesar 1.49 , serta nilai koefisien Nash Sutcliffe (ENS) yang mendekati nilai 1 yang masuk kedalam kategori baik $(0<E N S<1)$. Hasil validasi rumus empiris Talbot dengan intensitas hujan pengamatan menunjukkan kinerja yang bagus yang ditunjukkan dengan nilai deviasi rata-rata sebesar 2.22, nilai kesalahan relatif $(K r)$ rata-rata sebesar $15.11 \%$, dan koefisien Nash Sutcliffe $(E N S)$ rata-rata mendekati $1(0.93)$ dimana dapat diklasifikasikan dalam kategori kinerja yang baik. Hasil penggambaran kurva Intensitas Durasi Frekuensi $(I D F)$ rumus Talbot pada kala ulang 2 dan 5 tahun menunjukkan pola 
dimana semakin besar kala ulangnya semakin besar penyimpangan yang terjadi antara intensitas hujan rumus Talbot dengan intensitas hujan pengamatan berdasarkan konsep peluang dan kala ulang. Berdasarkan hasil studi yang telah diperoleh, maka dapat disimpulkan bahwa rumus Talbot memiliki keandalan yang cukup baik dan layak digunakan untuk memperkirakan nilai intensitas hujan dan kurva Intensitas Durasi Frekuensi $(I D F)$ pada berbagai kala ulang $(T r)$ dan durasi $(t)$.

\section{Daftar Pustaka}

Akpen, G.D., M.I. Aho, and A.A. Musa. 2019. "Rainfall Intensity-Duration-Frequency Models for Lokoja Metropolis, Nigeria." Global Journal of Pure and Applied Sciences 25(1): 81.

Asbintari, Syafutri, Rismalinda Rismalinda, and Rahmi Alfi. 2016. "Komparasi Metode Formulasi Intensitas Hujan Di Kawasan Hulu Daerah Aliran Sungai (DAS) Batang Lubuh Kota Pasir Pengaraian." Jurnal Mahasiswa Teknik UPP 2(1): 1-8.

Bhat, M. Sultan et al. 2019. "Flood Frequency Analysis of River Jhelum in Kashmir Basin." Quaternary International 507(June 2018): 288-94.

Cohn, T. A. et al. 2013. "A Generalized Grubbs-Beck Test Statistic for Detecting Multiple Potentially Influential Low Outliers in Flood Series." Water Resources Research 49(8): 5047-58.

Dar, Abdul Qayoom, Humairah Maqbool, and Syeedah Raazia. 2016. "An Empirical Formula to Estimate Rainfall Intensity in Kupwara Region of Kashmir Valley, J and K, India." MATEC Web of Conferences 57.

David, A. O., Ify L. Nwaogazie, and J. C. Agunwamba. 2019. "Development of Models for Rainfall Intensity- Duration-Frequency for Akure, South-West, Nigeria." International Journal of Environment and Climate Change 9(8): 457-66.

Ghazavi, Reza, Ali Moafi Rabori, and M Ahadnejad Reveshty. 2017. "The Effects of Rainfall Intensity-Duration-Frequency Curves Reformation on Urban Flood Characteristics in SemiArid Environment." Ecopersia 5(2): 1799-1813.

Guntoro, Dani Eko, Donny Harisuseno, and Evi Nur Cahya. 2017. "Pengelolaan Drainase Secara Terpadu Untuk Pengendalian Genangan Di Kawasan Sidokare Kabupaten Sidoarjo.” Jurnal Teknik Pengairan 008(01): 60-71.

Gutierrez-Lopez, Alfonso, Sergio Bernardo Jimenez Hernandez, and Carlos Escalante Sandoval. 2019. "Physical Parameterization of IDF Curves Based on Short-Duration Storms." Water (Switzerland) 11(9): 1-14.

Harisuseno, Donny, and Mohammad Bisri. 2017. Limpasan Permukaan Secara Keruangan (Spatial Runoff). First. Malang: UB Press.

Hendri, A. 2015. "Analisis Metode Intensitas Hujan Pada Stasiun Hujan Pasar Kampar Kabupaten Kampar.” In Annual Civil Engineering Seminar, , 297-304.

Inayathulla, M, Mohammed Rafi, and Civil Engineering. 2019. "Hydrologic Analysis of Watershed by Generation of Rainfall Intensity Duration Frequency Curves." International Journal of Innovative Research in Technology 6(7): 30-36.

Jahnvi, Ms, P Bhatt, H M Gandhi, and K B Gohil. 2014. "Generation of Intensity Duration Frequency Curve Using Daily.” Journal of International Academic Research for Multidisciplinary 2(2): 717-22.

Limantara, L.M., D.H. Harisuseno, and V.A.K. Dewi. 2018. "Modelling of Rainfall Intensity in a Watershed: A Case Study in Amprong Watershed, Kedungkandang, Malang, East Java of Indonesia." Journal of Water and Land Development 38(1).

Montesarchio, V. et al. 2015. "Comparison of Methodologies for Flood Rainfall Thresholds Estimation." Natural Hazards 75(1): 909-34.

Nhat, Le minh, Yasuto Tachikawa, and Kaoru Takara. 2006. "Establishment of Intensity-DurationFrequency Curves for Precipitation in the Monsoon Area of Vietnam." Annual od Disaster Prevention Research Institute 49B: 93-103. 
De Paola, Francesco et al. 2018. "GEV Parameter Estimation and Stationary vs. Non-Stationary Analysis of Extreme Rainfall in African Test Cities." Hydrology 5(2).

Rangsiwanichpong, Prem, So Kazama, and Chaiwat Ekkawatpanit. 2017. "Analysing the Relationship between Ocean Indices and Rainfall in the Chao Phraya River Basin." International Journal of Climatology 37: 230-38.

Rismasari, Rahma, Donny Harisuseno, and Andre Primantyo Hendrawan. 2018. "Kajian Penanggulangan Genangan Yang Terintegrasi Di Kawasan Pilang, Probolinggo.” Jurnal Teknik Pengairan 9(1): 47-59.

Roghani, Rabbaneh, Saeid Soltani, and Hossein Bashari. 2016. "Influence of Southern Oscillation on Autumn Rainfall in Iran (1951-2011)." Theoretical and Applied Climatology 124(1-2): 411-23.

Salman, Saleem A. et al. 2018. "Unidirectional Trends in Daily Rainfall Extremes of Iraq." Theoretical and Applied Climatology 134(3-4): 1165-77.

Subyani, Ali M., and Nassir S. Al-Amri. 2015. "IDF Curves and Daily Rainfall Generation for AlMadinah City, Western Saudi Arabia." Arabian Journal of Geosciences 8(12): 11107-19.

Suharyanto, Agus. 2016. "Prediction of Flood Area Based on the Occurrence of Rainfall Intensity." GMSARN International Journal 10: 129-36.

Susilowati. 2012. "Analyze the Characteristic of Rainfall and Intensity Duration Frequency ( IDF ) Curve at Lampung Province." 1st International Conference on Enginering and Technology Development: 161-73.

Tfwala, C. M. et al. 2017. "Precipitation Intensity-Duration-Frequency Curves and Their Uncertainties for Ghaap Plateau." Climate Risk Management 16(April): 1-9.

Vanitha, S, and V Ravikumar. 2017. "Construction of Intensity-Duration-Frequency (IDF) Curves for Precipitation with Annual Maxima Data Kumulur Region." International Journal of Bioresource and Stress Management 8(5): 721-26.

Wagesho, Negash, and Marie Claire. 2016. "Analysis of Rainfall Intensity-Duration-Frequency Relationship for Rwanda." Journal of Water Resource and Protection 08(07): 706-23.

Zope, P. E., Eldho T. I., and V. Jothiprakash. 2016. "Development of Rainfall Intensity Duration Frequency Curves for Mumbai City, India." Journal of Water Resource and Protection 08(07): 756-65. 